\title{
Analysis of Detergent Waste Absorption Using Water Spinach (Ipomoea aquatica)
}

\author{
Syarifa Wahidah Al-Idrus* ${ }^{* 1}$, R. Rahmawati ${ }^{1}$, Saprizal Hadisaputra1, Hilman Qudratuddarsi² \\ ${ }^{1}$ Study Program of Chemistry, Department of Education of Mathematics and Natural Sciences, Universitas Mataram, Jalan Majapahit 62, \\ Mataram, Indonesia. \\ ${ }^{2}$ Mathematics and Science Education Department, Faculty of Education, University of Malaya, University Street, Kuala Lumpur, Malaysia
}

DOI: $\underline{10.29303 / \text { jossed.v2i1.483 }}$

\section{Article Info}

Received : September $24^{\text {th }}, 2020$

Revised : April 10th, 2021

Accepted: April 21 th, 2021

\begin{abstract}
This study aims to determine the absorption of water detergent waste using water spinach (ipomoea aquatica). This experimental study used a randomized block design. Water samples were planted with water plants according to the research design. Detergent concentrations were observed using the MBAS (Methylene Blue Active Substance) method. The results showed that water spinach was able to reduce the detergent concentration and improve the concentration of water quality parameters (DO, BOD, and COD). After the treatment of water kangkong, the ability to absorb detergent was seen with a decrease in detergent levels until day 28 of $54.17 \%$. The highest detergent absorption on days 7 and 14 .
\end{abstract}

Keywords: absorption; detergent waste; water spinach

Citation : Al Idrus, S., Rahmawati, R., Hadisaputra, S., \& Qudratuddarsi, H. (2021). Analysis of Detergent Waste Absorption Using Water Spinach (Ipomoea aquatica). Journal of Science and Science Education, 2(1), 17-21. doi:https://doi.org/10.29303/jossed.v2i1.483

\section{Introduction}

Detergent is a synthetic cleaning agent that is used by industry and households. Detergents contain petrochemical ingredients or other synthetic surfactants. The advantage of detergent is that it has good washing power and is not affected by water hardness. Hard water is water that contains mineral ions such as $\mathrm{Ca}, \mathrm{Fe}, \mathrm{Mg}$, and $\mathrm{Mn}$. The weakness of detergents is that they contain active substances that are difficult to degrade by microorganisms.

The active substances contained in detergents are surfactants, builders, $\mathrm{pH}$, buffers, and other addictive substances (Yangzin, 2008). The largest composition of detergents is surfactants, namely $15 \%$ to $40 \%$ (Yangxin, 2008). The surfactants in detergents consist of anionic, cationic, and nonionic surfactants. A good surfactant for cleaning is anionic surfactant. The detergent degradation process is difficult to do because in the detergent molecular structure there are branched chains on the carbon atoms as shown in Figure 1.

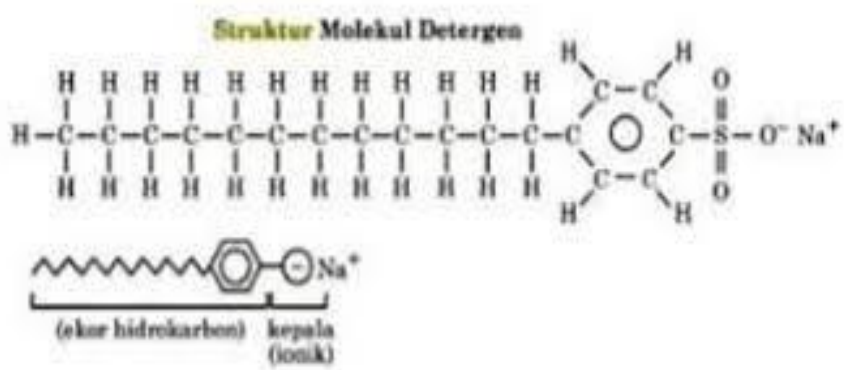

Figure 1. Detergent Molecular Structure Source/retrieved from: eprint.uny.ac.id

According to Suharjono (2010), the community needs detergent as a cleaning agent, and it will produce detergent waste. Detergent waste dissolved in water can inhibit photosynthesis in water and reduce oxygen supply. Phosphate compounds in detergents can cause 
eutrophication in water. Eutrophication is a process of enrichment of nutrients and organic matter in water so that phytoplankton and algae bloom in the water. In high amounts it will endanger water quality, low dissolved oxygen, and toxic gases and toxic materials (cvarrotoxin) appear (Sugrura et al, 2004; Pattusamy, et al., 2013; Nair, Suka.S. et al., 2015; Wijayanti. 2008). The low amount of dissolved oxygen is an indication of pollution in the waters. So it is necessary to look for an alternative waste treatment that is easy, cheap, and effective in its application.

One of the effective methods is the absorption of waste using water plants. According to Stowell, water plants are able to neutralize certain substances in the waters. Water plants that are often used in the process of absorption of waste are apu wood, genjer, water spinach, water hyacinth and kiambang. Water hyacinth (Eichornia crassipes), water spinach (Ipomoea aquatica) and apu wood (Pistia stratiotes) can accumulate and tolerate toxic metals $(\mathrm{Ag}, \mathrm{Cd}, \mathrm{Cr}, \mathrm{Cu}, \mathrm{Hg}, \mathrm{Ni}, \mathrm{Pb}$, and $\mathrm{Zn)}$ (Odjegba, et al, 2004). The plants are used to reduce phosphate and sulfate levels in waters (Hernawati 2005). In this study, water spinach (ipomoea aquatica) was used because it is able to absorb waste. According to Lusiani La Tiro (2018) water spinach (Ipomoea aquatic) is able to absorb lead $(\mathrm{Pb})$ and copper $(\mathrm{Cu})$ metals in the water. Water spinach is able to absorb cadmium (Cd) from the waters of Resmaya Wulandari (2014). The use of water spinach as a method of absorption of waste is quite effective and efficient because the water spinach plant is very popular on the island of Lombok as a typical plant. This study aims to determine the ability of water spinach plants, which are typical plants on the island of Lombok, to absorb detergent waste in the water.

\section{Method}

This study used a sample from detergentcontaminated waters. The sampling point is a section of the river in the densely populated downstream area with detergent content greater than $0.12 \mathrm{mg} / \mathrm{l}$, river width $9.0 \mathrm{~m}$, relatively weak river current $0.03 \mathrm{~m} / \mathrm{s}$, brown water, and fishy smell. Water samples were taken using a water sampler cammer at a predetermined point. Then analysis of water sample quality parameters $(\mathrm{pH}, \mathrm{DO}, \mathrm{BOD}$, and $\mathrm{COD})$ and detergent content was carried out.

The plant sample used in this study was water spinach (Ipomoea aquatic). The water spinach used is local water spinach that has been taken and acclamated to remove dirt from the roots. The design in this study was a randomized block design (RBD). Group A is the type of plant $(\mathrm{K} 0, \mathrm{~K} 1)$ and group $\mathrm{B}$ is the time / period (H0, H7, H14, H21 and H28). Water samples that have been analyzed for the initial physics and chemistry parameters were divided into 6 observation tanks for block 1, block 2 and block 3 (K0 repetition (control). K1, observation tub containing water samples and planted with water spinach (ipomoea aquatic). The mass of water plants planted in the observation tub is $65 \mathrm{~g}$ Block 2 and block 3 are repetitive treatments such as block 1. Every day period (H0, H7, H14, H21, and H28) is observed water quality.

The water quality analysis included physical and chemical analysis (temperature, $\mathrm{pH}, \mathrm{DO}, \mathrm{BOD}, \mathrm{COD}$, and detergent content) before and after treatment. $\mathrm{PH}$ measurement using a $\mathrm{pH}$ meter. DO analysis (dissolved oxygen) using a DO meter. On the fifth day, BOD (biological oxygen demand) measurements are carried out using a DO meter. The difference between DO5 and $\mathrm{DO} 0$ is the BOD value. COD analysis was performed by titration method using potassium dichromate (K2Cr2O7) oxidizing agent. Detergent content was tested in the laboratory using the MBAS (Methylene Blue Active Substance) method.

\section{Result and Discussion}

The preliminary data from the water samples show quite high detergent levels. This is due to the people's habit of disposing of their domestic liquid waste directly into the river. According to Rochman (2009) detergent is a domestic liquid waste with the largest volume. The results of initial observations are shown in:

Table 1. Sample water quality at the beginning of the study

\begin{tabular}{llccc}
\hline No & Parameter & Unit & \multicolumn{3}{c}{$\begin{array}{l}\text { PP Quality } \\
\text { Result } \\
\text { Standards No. } \\
\text { 82 of 2001 class } \\
\text { II }\end{array}$} \\
\hline 1 & $\begin{array}{l}\text { Detergen } \\
\text { (MBAS) }\end{array}$ & $\mathrm{mg} / \mathrm{L}$ & 0,12 & 0,02 \\
2 & $\begin{array}{l}\text { Dissolved } \\
\text { Oxygen (DO) }\end{array}$ & $\mathrm{mg} / \mathrm{L}$ & 4,3 & 4 \\
3 & $\begin{array}{l}\text { Biological } \\
\text { Oxygen } \\
\text { Demand (BOD) }\end{array}$ & $\mathrm{mg} / \mathrm{L}$ & 5,6 & 3 \\
4 & $\begin{array}{l}\text { Chemical } \\
\text { Oxygen }\end{array}$ & $\mathrm{mg} / \mathrm{L}$ & 40,7 & 25 \\
& $\begin{array}{l}\text { Demand (BOD) } \\
\text { pH }\end{array}$ & - & 6,9 & $6-9$ \\
6 & Temperature & ${ }^{\circ} \mathrm{C}$ & 28,5 & - \\
\hline
\end{tabular}

Table 2. Changes in waterquality parameter values.

\begin{tabular}{lllllll}
\hline No. & $\begin{array}{l}\text { Water quality } \\
\text { parameters }\end{array}$ & $\mathrm{H} 0$ & $\mathrm{H} 7$ & $\mathrm{H} 14$ & $\mathrm{H} 21$ & $\mathrm{H} 28$ \\
\hline 1. & Detergent & 0,12 & 0,073 & 0,065 & 0,057 & 0,055 \\
2. & DO & 4,3 & 6,8 & 6,55 & 5,45 & 5,2 \\
3. & BOD & 5,6 & 4,3 & 3,5 & 2,9 & 3,8 \\
4. & COD & 40,7 & 36,7 & 33,8 & 32,8 & 31,6 \\
\hline
\end{tabular}


Table 1, shows the water sample quality is above the Class II water level and is categorized as polluted. One of the causes of this pollution is the entry of domestic waste into rivers. Domestic waste mostly contains detergents which are difficult to degrade. Detergent waste will inhibit the solubility of oxygen in water so that DO is low and BOD and COD become high. In addition, the phosphate content in detergents causes the development of freshwater plants, such as algae (which use available oxygen for the decomposition process) so that dissolved oxygen (DO) becomes low (Cohen \& Keizer, 2017).

In the observation bath without plants (K0), the detergent content did not decrease significantly. From day $0(0.12 \mathrm{mg} / \mathrm{l})$ to day $28(0.115 \mathrm{mg} / \mathrm{l})$. This is because detergents cannot be degraded by microorganisms in water. Detergent levels in water samples planted with water spinach / ipomoea aquatica (K2) decreased. Decrease in detergent levels after treatment is shown in Figure 1.

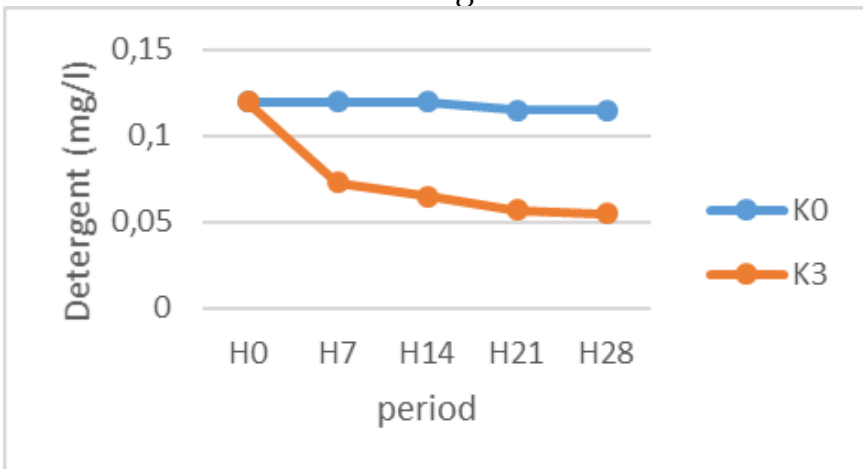

Figure 1. Detergent value at 5 day periods.

Observations were started on the 7th day after planting water spinach in the water sample. Detergent levels decreased significantly from $0.12 \mathrm{mg} / \mathrm{L}$ to 0.073 $\mathrm{mg} / \mathrm{L}$. This condition is caused by water spinach to absorb chemicals in the waste as nutrients for growth. According to Padmaningrum (2014) in the absorption process using plants, chemical substances contained in waste will be used as nutrients for growth. The absorption process carried out by plants takes three steps (Rosiana, 2007).

Observations on days 14 and 21, detergent experienced a good decrease. This is because water spinach still needs nutrients to grow, as seen by the growth of several kale shoots. On the 28th day of observation, the detergent experienced a small decrease, because the volume of water began to decrease, and the condition of the water did not flow so that plant growth could not be maximized.

Dissolved Oxygen is the concentration of dissolved oxygen in water. Dissolved oxygen in water is obtained through diffusion from air into water, mechanical aeration, and photosynthesis of aquatic plants. Meanwhile, dissolved oxygen in water can be reduced due to respiration and decay of organic matter at the bottom of the waters (Department of Primary Industries and Resources of South Australia, 2003).

Dissolved oxygen (DO) of water samples in the control did not change significantly. In the treatment with water spinach, there was an increase in DO to 6.8 $\mathrm{mg} / 1$ on day 7 . On day 14 the DO value occurred to be $6.55 \mathrm{mg} / 1$. During the 21st and 28th days, the DO value has decreased as shown in Figure 2. The decline that occurred on days 21 and 28 was due to some of the kale leaves decaying. Rotten leaves will need dissolved oxygen. The pattern of changes in DO values can be seen in Figure 2.

In addition, data retrieval time affect the DO value of the water sample. According to Connell and Miller in Hermawati et all. (2005), that DO is maximal during the day and evening and continues to decrease until just before dawn. The maximum dissolved oxygen content during the day because at that time the plant is actively doing photosynthesis so that a lot of oxygen is produced

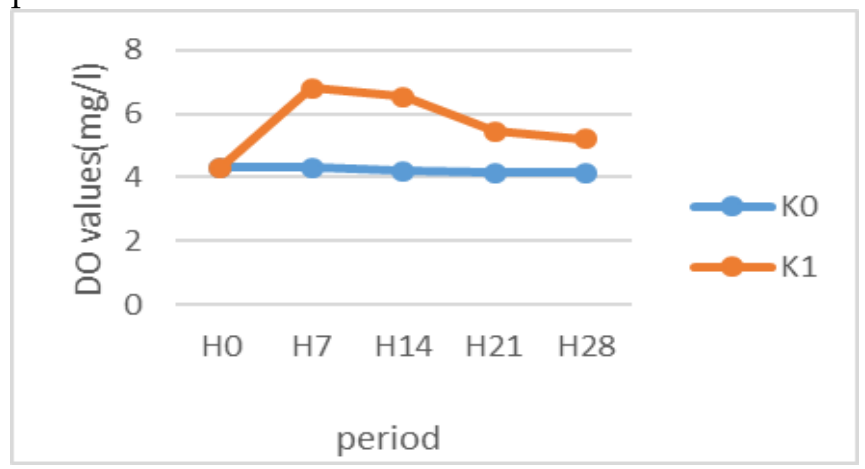

Figure 2. DO values at 5 periods

BOD is the amount of oxygen needed by bacteria to break down dissolved organic substances and some of the organic substances suspended in water. One of the organic substances found in the waters is detergent. BOD in the control water sample did not change. Water samples (K1) decreased BOD on days 7 and 14 to 4.6 $\mathrm{mg} / 1$ and $3.8 \mathrm{mg} / \mathrm{l}$. The period of day 21 , the smallest $\mathrm{BOD}$ on the period of day 21 is $1.9 \mathrm{mg} / \mathrm{l}$. then period 28 , the BOD value increased slightly to $2.2 \mathrm{mg} / \mathrm{l}$.

A decrease in BOD as an indicator of decreased organic derivate content. Decrease in organic matter derivatives will reduce the use of oxygen in the waters. A decrease in BOD will be proportional to an increase in DO. The pattern of BOD value adjustment is shown in Figure 3. 


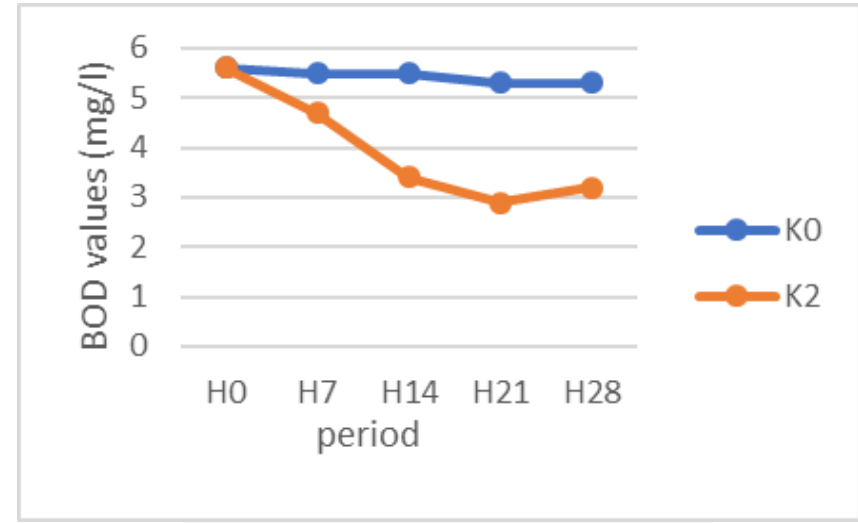

Figure 3. BOD values at 5 day periods.

Chemical Oxygen Demand (COD) is the amount of oxygen in ppm or $\mathrm{mg} / \mathrm{l}$ needed under special conditions to chemically decompose organic matter, (Devi Ramayanti, 2019). The COD value in the water sample on the first day was quite high, namely $40.7 \mathrm{mg} / \mathrm{l}$, which was above the class II water quality standard. A high COD value indicates that the water is polluted (Dewa and Idrus, 2017). The high COD value indicates the presence of organic substances in large amounts of water samples. Organic substances can convert oxygen into $\mathrm{CO} 2$ and water, resulting in a decrease in oxygen in the waters. An increase in COD in water causes a decrease in dissolved oxygen in the waters (Sami, 2012).

COD of control water sample $(\mathrm{K} 0)$, did not experience significant changes during the 5 day period of observation. COD of water samples (K1) with water spinach planting treatment, decreased significantly in the 7 -day observation period of $36.7 \mathrm{mg} / 1$. on day 14 it continued to decrease to $33.8 \mathrm{mg} / 1$, on day 21 the COD value was $32.8 \mathrm{mg} / 1$ and on day 28 it became 31.6 $\mathrm{mg} / 1$. a significant decrease is due to water spinach absorbing organic substances in the waters. The pattern of COD reduction in this study can be seen in Figure 4.

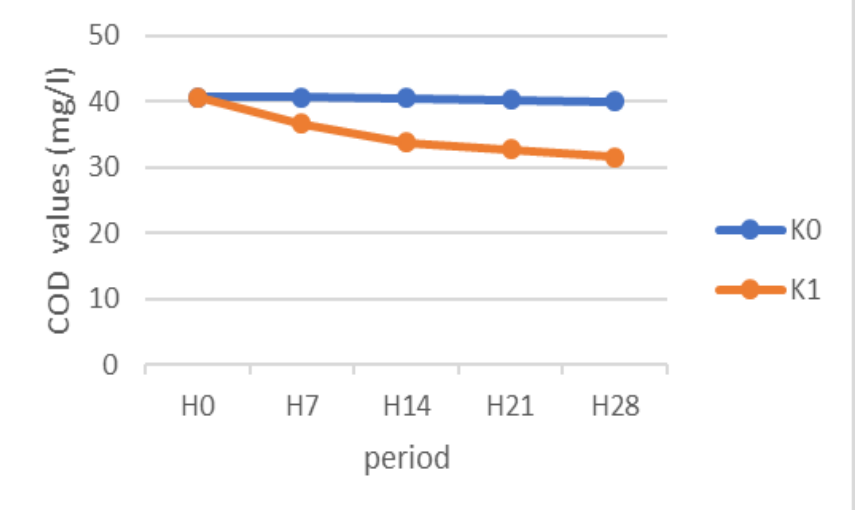

Figure 4 . COD values at 5 day periods.
Table 3.Percentage of Water Quality Improvement After Treatment (K1)

\begin{tabular}{lllll}
\hline No. & $\begin{array}{l}\text { Water } \\
\text { quality } \\
\text { parameter }\end{array}$ & $\begin{array}{l}\text { Preliminary } \\
\text { data }(\mathrm{mg} / \mathrm{l})\end{array}$ & $\begin{array}{l}\text { Data day } \\
28(\mathrm{mg} / \mathrm{l})\end{array}$ & $\begin{array}{l}\% \\
\text { Change }\end{array}$ \\
\hline 1. & Detergent & 0,12 & 0,055 & 54,17 \\
2. & DO & 4,3 & 5,2 & 20,93 \\
3. & BOD & 5,6 & 3,8 & 32,14 \\
4. & COD & 40,7 & 31,6 & 22,36 \\
\hline
\end{tabular}

\section{Conclusion}

Water spinach (Ipomoea aquatica) is a typical plant on the island of Lombok. Water spinach has the ability to absorb detergent waste in the water. The ability to absorb the best detergent on the 7th and 14th day period. The 7 th and 14 th period also gave the best results for other parameters (DO, BOD and COD). The results showed that the detergent levels after treatment decreased to $54.17 \%$. DO has increased by $20.93 \%$, BOD and COD have decreased by $32.14 \%$ and, respectively, $36 \%$.

\section{References}

Cohen, A., \& Keiser, D. A. (2017). The effectiveness of incomplete and overlapping pollution regulation: evidence from bans on phosphate in automatic dishwasher detergent. Journal of Public Economics. 150(2) pp. 53-74. doi: https://doi.org/10.1016/j.jpubeco.2017.03.005

Dewa, R. P., \& Idrus, S. (2017). Identification of tofu industrial wastewater contamination in Ambon city , BIAM Magazine, 13(2), pp. 11-15. doi: http://dx.doi.org/10.29360/mb.v13i2.3544

Hermawati, E. (2005). Phytoremidiation of detergen waste using pistia stratiotes $\mathrm{L}$ and Limnocharis flava L. Journal BioSMART, 7,(2). pp. 115-124. Retrieved from https://biosmart.mipa.uns.ac.id/index.php/bio smart/\%20article/viewFile/9/10

Nair, S.S., \& Swarnalatha, K. (2015). Biodegradation of laundry wastewater, International Research Journal of Engineering and Technology (IRJET), 2(3). pp. 789-793. Retrieved from https://www.irjet.net/archives/V2/i7/IRJETV2I7122.pdf

Odjegba, V.J. \& Fasidi, I.O. (2004). Accumulation of trace elements by Pistia stratiotes: Implications for phytoremediation. Ecotoxicol. 13: 637-646. Doi: https://doi.org/10.1007/s10646-003-4424-1oi

Padmaningrum, R. T. (2014). Biomass effect of water jasmine (Echinodorus paleafolius) and lotus (Nymphaea firecrest) on levels of Phosphate, BOD, COD, TSS and the degree of acidity of 
Laundry wastewater. Jurnal Penelitian Saintek, 19(2), 64- 74. doi: https://doi.org/10.21831/jps.v19i2.3504

Pattusamy, V., Nandini, N., \& Bheemappa, K. (2013). Detergent and sewage phosphates entering into lake ecosystem and Its impact on aquatic environment, International Journal Of Advanced Research, vol.1, pp 129-133. Retrieved from https://www.journalijar.com

Primary Industries \& Resources South Australian. (2003). Ecological assessment of the south australian rock lobster (Jasus edwardsii) Fishery. South Australian Fisheries Management Series. https://www.environment.gov.au/system/files $\angle$ pages/6f5f44b4-2b9c-41df-b8169ef355815f6b/files/submission.pdf

Ramayanti, D., \& Amna, A. (2019). Parameter analysis of COD (Chemical Oxygen Demand) and $\mathrm{pH}$ (potential Hydrogen). Quimica: Jurnal Kimia Sains dan Terapan. 1(1), 16-21. Retrieved from https://ejurnalunsam.id/index.php/JQ/article/ view/1689

Rochman, F. (2009). Manufacture of mini IPAL for domestic detergent waste. Journal of Exact Research, 8(2), 134- 142. Retrieved from http://www.journal.unair.ac.id/downloadfullpapers06\%20vol\%207\%20no\%202\%20Agts \%202009\%20 FST\%20_faidur\%20rohman_\%20125-133.pdf

Rosiana, N. (2007). Phytoremediation of liquid waste with water hyacinth (Eichhornia crassipes (Mart) Solms) and solid waste from the petroleum industry with sengon (Paraserianthes falcataria $l$. Nielsen) with mycorrhiza. Research Report. Bandung: Universitas Padjajaran. http://pustaka.unpad.ac.id/archives/10668

Sami, M. (2012). Removal of COD, TSS, and $\mathrm{pH}$ in domestic wastewater by fixed-bed column up flow method, Journal of Science and Technology. 10 (21), pp.1-11. Retrieved from http://jurnal.pnl.ac.id/wpcontent/plugins/Flutter/files_flutter/1365647971reaks iPakSami.pdf

Sugiura, N., M. Utsumi, B. Wei, N. Iwami, K. Okano, Y. Kawauchi, T. Maekawa. (2004). Assessment for the complicated occurrence of nuisance odours from phytoplankton and environmental factors in a eutrophic lake. Lake $\mathcal{E}$ Resenoirs: Res.and Mqn., 9(l) 95-201. doi: https://doi.org/10.1111/j.14401770.2004.00246.x

Tiro, L.L., Isa, I., Iyabu, H. (2017). Potential of water spinach (Ipomoea Aquatica) as bioabsorption of $\mathrm{Pb}$ and $\mathrm{Cu}$ metals. Jurnal Entropi. 12 (1). pp. 8186. Retrieved from https://media.neliti.com/media/publications/2 77663-potensi-tanaman-kangkung-air-ipomoeaaqu-dd1f6f7e.pdf

Wulandari, R., Purnomo, T., dan Winarsih. (2014). The ability of water spinach (Ipomoea aquatica) to absorb heavy metal cadmium (Cd) based on different concentrations and exposure times the ability of water spinach (Ipomoea aquatica) to absorb cadmium (Cd) in different concentration and exposure time. Lentera Bio. 3(2) pp. 83-89. Retrieved from http://ejournal.unesa.ac.id/index.php/lenterabi o

Yangxin, Y.U., Jin, ZHAO., Bayly, A.E. (2008). Development of surfactan and builder in detergent formulations. Chinese Journal of Chemical Enggineering. 16(4) 517-527. doi: https://doi.org/10.1016/S1004-9541(08)60115-9 